\title{
ASSESSMENT OF AMBIENT AIR QUALITY AND DEVELOPMENT OF GREEN BELT AROUND INDUSTRIES IN ASSAM USING SELECTIVE TREE AND PLANT SPECIES
}

\author{
Jiban Jyoti Das
}

Article DOI: https://doi.org/10.36713/epra4575

\begin{abstract}
Industrialization is an important aspect of a growing economy. However, rapid industrialization has caused many serious impacts on the environment. One such impact is the deteriorating air quality, especially around industries. It is said that afforestation is the best and simplest way for improving the air quality. Also, trees and plants have been increasingly used as filters for dust particles around the home, traffic roads, etc. In scientific studies, it has also been found that trees and plant leaves can be used to assess the ambient air quality by an index called the Air pollution tolerance index. A literature search has been done on the scientific database like Sciencedirect and Researchgate to review the existing knowledge of Air pollution tolerance index and to find the tolerant and sensitive species based on it so that these species can be selectively planted to assess the ambient air quality and also to develop a better green belt around refineries and industries in Assam. The study has reviewed the linkage of the impact of air pollution on leaves of plants and trees through scientific evidence. Through such scientific reviews, the most tolerant species of trees and plants were chosen with the condition that it can grow under the climatic condition of Assam. The recommendation and suggestions of tolerant tree and plant species can be used for specific species plantations for developing green belts around refineries and industries in Assam. The recommendation of sensitive species can be used for monitoring ambient air quality with reference to other standard procedures.
\end{abstract}

KEYWORDS: Air pollution tolerance index, Industries, Air-pollution, Green belt

\section{INTRODUCTION}

Due to rapid industrialization and urbanization, air quality has been deteriorating day by day. Industries release many harmful pollutant chemicals from stack emission which can impact the air quality around it. Also heavy vehicular movements around industries release dust and other pollutants in the air.

Since leaves are exposed to air all the time, the deposition of dust and atmospheric pollutants on them may have negative impact on them. Dust depositions can cover the leaves blade restricting them to receive direct sunlight for proper photosynthesis [1]. Studies has shown that plants are quite sensitive to pollutants like $\mathrm{CO}, \mathrm{SO}_{2}$ and $\mathrm{NO}_{2}$ and high dosage of such pollutants in longer run can lead to leaf necrosis, growth inhibition and may cause plant death [2].

Other effects of pollutants on leaves include variation in ascorbic acid content [3], Chlorophyll content [4], leaf extract $\mathrm{pH}$, and relative water content. The Air Pollution tolerance index is an index based upon these four biochemical parameters defines a species of plant and trees to be sensitive or tolerance against interactions with air pollutants. Through scientific research and reviews of the Air Pollution tolerance index, the most tolerant species of plants were chosen with the condition that it can grow under the climatic condition of Assam. The recommendation and suggestions of such tree species can be used for specific species plantations for developing green belts around refineries and industries in Assam. Also sensitive plant species can be used as ecological indicators for qualitative assessment of ambient air quality around the refineries and industries in Assam.

\section{RELATED STUDIES}

\section{A. Air Pollution tolerance IndeX}

Air pollution tolerance index is an empirical relation[5] that evaluates the tolerance level of plant and tree species to categorized them into sensitive or tolerant to the impacts of air pollutants. It is based upon the biochemical parameters mentioned below.

a) Ascorbic acid: Studies highlighted the highest correlation between Sulphur dioxide(SO2) sensitivity and ascorbic acid content in plant leaves[3]. 
b) Chlorophyll: Reduction of chlorophyll has been observed to be more in plant and tree species growing in polluted areas as compared to less polluted areas[4].

c) Relative water content: Studies have shown variation in relative water content under air pollution stress. Relative water content refers to the capacity of the cell membrane to maintain its permeability [6] .Cell membrane permeability is involved in the loss of dissolved nutrients and water in plants and trees and therefore the high relative water content of the leaf ensures they are thriving in a polluted environment for its physiological balance under pollution stress[7].

d) $\mathrm{pH}$ of the leaf extract: Studies have shown the variation of $\mathrm{pH}$ under polluted environment. Leaves of plants and trees whose $\mathrm{pH}$ has shown to decrease under polluted environment are sensitive towards pollution. A higher level of $\mathrm{pH}$ in leaf extract indicates that the plants are tolerant under polluted conditions. $\mathrm{pH}$ plays an important role in signifying the condition of plants with respect to the study area[6].

Equation for APTI is mentioned below.

$\mathrm{APTI}=\mathrm{A}(\mathrm{T}+\mathrm{P})+\mathrm{R} / 10$

Where $\mathrm{A}=$ ascorbic acid content $(\mathrm{mg} / \mathrm{g})$

$\mathrm{T}=$ total Chlorophyll (mg/g)

$\mathrm{R}=$ relative water content of leaf $(\%)$

$\mathrm{P}=\mathrm{pH}$ of leaf extract

Plant and tree species are categorized into sensitive species when the Air Pollution tolerance index is below 11, while above 11 is considered to be tolerant species. Species showing the Air Pollution tolerance index more than 17 are considered to be highly tolerant. The categorization was based as mentioned by the first formulator of the index[8]. However in recent times other parameters like canopy structure, type of tree, laminar characters, economic value along with APTI index has been used to formulate other strong parameters like the Anticipated performance index[9].

\section{B. Plants and pollutant interactions}

Leaves interaction with dust, Suspended matter, Sulphur dioxide $\left(\mathrm{SO}_{2}\right)$, Nitrogen dioxide $\left(\mathrm{NO}_{2}\right)$ and other oxides of Nitrogen $\left(\mathrm{NO}_{\mathrm{X}}\right)$ and carbon monoxide $(\mathrm{CO})$ has been reviewed as these five pollutants are common to every industries.

\section{Dust and Suspended Particulate Matter}

Physical characteristics of leaves like shape, trichomes, and stomata significantly get affect by accumulation of dust and particulate matters[10]. Dust and particulate matter when deposited over the leaf surface, clogs stomata apertures and prevents the exchange of gases by leaves reducing the rate of photosynthesis[1].

$\mathrm{SO}_{2}$

Leaves absorb $\mathrm{SO}_{2}$ via stomata. Inhibition of photosynthesis can take place if $\mathrm{SO}_{2}$ is hydrated and oxidized to sulfite and sulfate in higher concentrations at apoplastic $\mathrm{ph}[10]$. This can cause $\mathrm{SO}_{2}$ toxicity with symptoms like interveinal chlorosis and necrosis in broad-leaved species and chlorotic spots and brown tips specially when observed in pine conifers[11].

$\mathrm{NO}_{2}$ AND NO

Impact of leaves on interaction with $\mathrm{NO}$ and $\mathrm{NO}_{2}$ is much less than interaction with $\mathrm{SO}_{2}$ as these are required as nutrients by the plants and trees. $\mathrm{NO}$ and $\mathrm{NO}_{2}$ are absorbed and dissolved in the extra-cellular fluid matrix of leaves, are absorbed and dissolved and forms nitrate $\left(\mathrm{NO}_{3}\right)$ and $\mathrm{NO}_{2}$ in equal amounts and proton $\left(\mathrm{H}^{+}\right)[10] . \mathrm{NO}_{3}$ is then utilized by plants for synthesizing amino acids and proteins. However symptoms of overexposure of $\mathrm{NO}_{2}$ include irregular brown or black spots[10].

CO

Study of the effect of $\mathrm{CO}$ in some plants showed epinastic growth of leaves, hyponasty causing upward curling of leaves, retarded stem elongation, abnormally small leaves, yellowing of leaves and hypertrophied tissues on stems and roots[12].

\section{STUDY-RELATED TO APTI VALUES AROUND INDUSTRIAL AREAS}

Scientific studies were done through in depth analysis of scientific papers of research taken only around industrial areas. Areas outside industries were not taken for study.

In a study of Air Pollution tolerance index of tree and plant species around industries, it has been found scientifically that Air pollution tolerance index can be used for selection of suitable species for better planning of developing green belt around industrial and urban areas [13].

In a study of APTI values of trees in three areas ( residential, commercial and industrial ) the quality of air with respect to particulates, $\mathrm{SO}_{2}$, and $\mathrm{NO}_{2}$ was also assessed on respective sites to evaluate the Air pollution tolerance index of the trees [14]. It was concluded through one way ANOVA that the obtained Air pollution tolerance index values to be highly significant at the industrial sites to that of the control site. Through this study it can be said that the Air pollution tolerance index values can be used as a qualitative method for assessing air quality through sensitive species and also the selection of tolerant species for green belt development around industries.

In a study conducted for the evaluation of some tree in three industrial locations of South Bengaluru, India the most tolerant tree species with respect to ATPI and heavy metal concentration were Ficus religiosa, Azadirachta indica and Pongamia pinnata [15]. These plants were considered to be tolerant species in the industrial areas. Further from the same study, the Air pollution tolerance index values were used to find the most polluted industrial area among three industrial areas.

In a study of assessment of Air pollution tolerance index of selected plants around the cement industry and control area, 


\section{EPRA International Journal of Research and Development (IJRD)}

Coimbatore, India it was found that among the species studied Mangifera indica, Bougainvillea species, Psidum quajava showed high APTI values [16]. Thevetia neriifolia, and Phyllanthus emblica showed low Air pollution tolerance index values.

In another study of Air pollution tolerance index of plants growing near a small scale industrial area showed that emission from even small scale industries can cause considerable impact on the vegetation growing in the vicinity [8]. The study observed that among the various biochemical parameters of the plant leaves, ascorbic acid content was found to be the most crucial factor providing tolerance to the plants against air pollution. Species found to be tolerant was suggested for greenbelt design to assist the air pollution management practices in industrial areas.

\section{METHODOLOGY}

Plant species that are suitable for growing in Assam and already available in the region has been only been sorted out and was classified as sensitive or tolerant on the basis of Air pollution tolerance index. Plants species with APTI value lying less than 11 have been considered sensitive while more than 17 have been considered tolerant.

Environmental factors like weather type of soil, location can cause variation in Air Pollution tolerance index results. There might be situations arise when a particular plant species can show the index values in the range of tolerance and in other locations in the range of sensitivity. Therefore, it is always better to take consider the trees or plants as sensitive or tolerant species by not just comparing Air Pollution tolerance index values, but also comparing the Air Pollution tolerance index values of the same plant species from a control region nearby which is not under pressure from pollutants.

If a significant variation is observed in the index value of the species near the industries to that of the same species in the control area, then we may conclude that species are tolerant or sensitive based upon the positive or negative difference of the index. A positive difference of the index of a particular species growing around the industrial area to that of the index growing in control area can be considered tolerant or if negative difference is observed the species can be considered to be sensitive.

\section{RESULT}

Table 1 shows the list of the trees and plants which has been found sensitive and tolerant based upon the Air Pollution tolerance index values. Trees and plants has been categorized into sensitive and tolerant species when the Air Pollution tolerance index value of that particular tree or plant is below and above 11 respectively and when the Air Pollution tolerance index value show a significant difference between the values of the industrial area and control area
Table 1 List of tolerant and sensitive plant species favorable for growing around refineries and industries in Assam.

\begin{tabular}{|c|c|c|}
\hline Species Name & Common name & Category \\
\hline $\begin{array}{l}\text { Holoptelea } \\
\text { integrifolia [14],[16]. }\end{array}$ & $\begin{array}{l}\text { Indian Elm } \\
\text { Assamese Name: NA }\end{array}$ & Tolerant \\
\hline Cassia siamea[14] & $\begin{array}{l}\text { Bombay Blackwood tree } \\
\text { Assamese Name: Sia Sunaru }\end{array}$ & Sensitive \\
\hline $\begin{array}{l}\text { Pongamia } \\
\text { Pinnata[14], [15]. }\end{array}$ & $\begin{array}{l}\text { Indian Beech Tree } \\
\text { Assamese Name: Korach }\end{array}$ & Tolerant \\
\hline $\begin{array}{l}\text { Bauhinia } \\
\text { variegata[14]. }\end{array}$ & $\begin{array}{l}\text { Kaachnar } \\
\text { Assamese Name: Kanchan gos }\end{array}$ & Sensitive \\
\hline $\begin{array}{l}\text { Azadirachta } \\
\text { indica. }[15][16][13]\end{array}$ & $\begin{array}{l}\text { Neem } \\
\text { Assamese Name: Neem goos }\end{array}$ & Tolerant \\
\hline $\begin{array}{l}\text { Ficus } \\
\text { Religosa[15][16][8]. }\end{array}$ & $\begin{array}{l}\text { Peepal } \\
\text { Assamese Name: Aanhot gos }\end{array}$ & Tolerant \\
\hline Mangifera indica[16]. & $\begin{array}{l}\text { Mangoe } \\
\text { Assamese Name: Aam }\end{array}$ & Tolerant \\
\hline $\begin{array}{l}\text { Bougainvillea } \\
\text { species[16]. }\end{array}$ & $\begin{array}{l}\text { Bougainvillea } \\
\text { Assamese Name: Kagoj ful } \\
\text { gos }\end{array}$ & Tolerant \\
\hline $\begin{array}{l}\text { Psidum } \\
\text { quajava[16][8]. }\end{array}$ & $\begin{array}{l}\text { Guava tree } \\
\text { Assamese Name: Madhuri am }\end{array}$ & Tolerant \\
\hline $\begin{array}{l}\text { Tamarindus } \\
\text { Indica[16]. }\end{array}$ & $\begin{array}{l}\text { Imli } \\
\text { Assamese Name: Tetuli }\end{array}$ & Tolerant \\
\hline $\begin{array}{l}\text { Thevetia } \\
\text { neriifolia[16]. }\end{array}$ & $\begin{array}{l}\text { Yellow oleander } \\
\text { Assamese Name: Korobi }\end{array}$ & Sensitive \\
\hline $\begin{array}{l}\text { Phyllanthus } \\
\text { emblica[16]. }\end{array}$ & $\begin{array}{l}\text { Aamla } \\
\text { Assamese Name: Aamlakhi }\end{array}$ & Sensitive \\
\hline $\begin{array}{l}\text { Dalbergia } \\
\text { lanceolaria[15]. }\end{array}$ & $\begin{array}{l}\text { Takoli } \\
\text { Assamese Name: Meda-luwa }\end{array}$ & Tolerant \\
\hline Delbergia sissoo[16]. & $\begin{array}{l}\text { North Indian rosewood } \\
\text { Assamese Name: Shisu gos }\end{array}$ & Sensitive \\
\hline Rosa Indica[16]. & $\begin{array}{l}\text { Rose } \\
\text { Assamese Name: Gulab }\end{array}$ & Sensitive \\
\hline Moringa oleifera [16]. & $\begin{array}{l}\text { Drumstick tree } \\
\text { Assamese Name: Sojina }\end{array}$ & Tolerant \\
\hline Aagle marmelos [16]. & $\begin{array}{l}\text { Indian bael } \\
\text { Assamese Name: Bel }\end{array}$ & Tolerant \\
\hline $\begin{array}{ll}\text { Albizia } & \text { lebbeck } \\
\text { india[16]. } & \\
\end{array}$ & $\begin{array}{l}\text { Indian Siris } \\
\text { Assamese Name: Sau koroi }\end{array}$ & Tolerant \\
\hline $\begin{array}{l}\text { Helianthus } \\
\text { annuus[16]. }\end{array}$ & $\begin{array}{l}\text { Coomon Sunflower } \\
\text { Assamese Name:Suryyamukhi }\end{array}$ & Sensitive \\
\hline $\begin{array}{l}\text { Ficus } \\
\text { benghalensis[8][16] }\end{array}$ & $\begin{array}{l}\text { Indian Banyan } \\
\text { Assamese Name: Botgos }\end{array}$ & Tolerant \\
\hline H.brasiliensis[8] & $\begin{array}{l}\text { Pará rubber tree } \\
\text { Assamese Name: Robor tree }\end{array}$ & Tolerant \\
\hline $\begin{array}{l}\text { Syzygium cumin } \\
{[8][15]}\end{array}$ & $\begin{array}{l}\text { Java Plum } \\
\text { Assamese Name: Kalajam }\end{array}$ & Tolerant \\
\hline
\end{tabular}

\section{V.CONCLUSION}

From the study of Air Pollution Tolerance Index of tree and plant species around industries from various scientific publications, trees and plants especially tolerant species were sorted out on the basis that they can be grown in Assam and already growing in the region.

Most of the trees mentioned have medicinal and economic values. Some of them can be used as an ornamental plant. Developing of green belt with the mentioned tree and plant species can also help in improving the carbon sequestration 


\section{EPRA International Journal of Research and Development (IJRD)

capacity around the area. The study therefore figures out successfully the list of tree and plant species that can be used for the qualitative assessments of the ambient air quality and development of the green belt around refineries and industries in Assam by the Air Pollution tolerant Index. The species mentioned can be used for plantation activities on occasions like Environment Day and Earth day.

\section{REFERENCE}

1. I. Gheorghe and I. Barbu, "The Effects of Air Pollutants on Vegetation and the Role of Vegetation in Reducing Atmospheric Pollution," 2011.

2. S. Muneer, T.-H. Kim, B. Choi, B. Lee, and J. Lee, "Effect of CO, NOx and SO2 on ROS production, photosynthesis and ascorbate-glutathione pathway to induce Fragaria $\times$ annasa as a hyperaccumulator," Redox Biol., vol. 2, Dec. 2013.

3. A. Chauhan, "Effect of SO2 on Ascorbic Acid Content in Crop Plants --First Line of Defence against Oxidative Stress, ” Int. J. Innov. Res. Dev. Vol. 4, Issue 11, Oct. 2015, Oct. 2015.

4. S. Giri, D. Shrivastava, K. Deshmukh, and P. Dubey, Effect of Air Pollution on Chlorophyll Content of Leaves, vol. 1. 2013.

5. S. K. Singh, D. N. Rao, M. Agrawal, J. Pandey, and D. Naryan, "Air pollution tolerance index of plants," $J$. Environ. Manage., vol. 32, no. 1, pp. 45-55, 1991.

6. S. Subramani and D. S., "APPLICATION OF AIR POLLUTION TOLERANCE INDEX IN ASSESSING THE AIR QUALITY," Int. J. Pharm. Pharm. Sci., vol. 7, no. 7 SE-Original Article(s), May 2015.

7. B. Sharma, S. Sharma, and S. Bhardwaj, EFFECT OF POLLUTION ON RELATIVE WATER CONTENT IN TEMPERATE SPECIES GROWING ALONG NATIONAL HIGHWAY 5 IN HIMACHAL PRADESH. 2017.

8. S. K. Bharti, A. Trivedi, and N. Kumar, "Air pollution tolerance index of plants growing near an industrial site," Urban Clim., vol. 24, pp. 820-829, 2018.

9. L. Panda, R. Aggarwal, and D. R. Bhardwaj, "A review on Air Pollution Tolerance Index (APTI) and Anticipated Performance Index (API), " Curr. World Environ., vol. 13, pp. 55-65, Apr. 2018.

10. X. Wei et al., "Phylloremediation of Air Pollutants: Exploiting the Potential of Plant Leaves and LeafAssociated Microbes ," Frontiers in Plant Science, vol. 8. p. 1318, 2017.

11. H. Rennenberg, "The Fate of Excess Sulfur in Higher Plants," Annu. Rev. Plant Physiol. Plant Mol. Biol., vol. 35, pp. 121-153, Nov. 2003.

12. P. W. Zimmerman, W. Crocker, and A. E. Hitchcock, "Effect of carbon monoxide on plants. [Mimosa pudica]," 1933.

13. M. Kaur, A. Sharma, J. Katnoria, and A. Nagpal, "Air Pollution Tolerance Index (APTI): An Important Determinant for the Development of Green Space in and Around Industrial/Urban Areas, " 2018.

14. A. Tripathi, P. Tiwari, Mahima, and D. Singh, "Assessment of air pollution tolerance index of some trees in
Moradabad city, India,” J. Environ. Biol., vol. 30, pp. 545550, Jul. 2009.

15. A. Begum and S. Harikrishna, "Evaluation of Some Tree Species to Absorb Air Pollutants in Three Industrial Locations of South Bengaluru, India," J. Chem., vol. 7, Dec. 2010.

16. P. Radhapriya, A. NavaneethaGopalakrishnan, P. Malini, and A. Ramachandran, "Assessment of air pollution tolerance levels of selected plants around cement industry, Coimbatore, India," J. Environ. Biol., vol. 33, pp. 635-641, May 2012. 